\title{
Rituals and Music in the Northern Zhou Dynasty
}

\author{
Xing Tang \\ School of Liberal Arts \\ Northwest Minzu University \\ Lanzhou, China
}

\begin{abstract}
The ritual system in the Northern Zhou Dynasty (including the Western Wei Dynasty) mainly was established in accordance with Rites of Zhou. But it didn't completely imitate it. It not only didn't recover five traditional rites entirely but also had innovative characteristics in the construction of the ritual system. This special ritual system also has the culture of both ethnic groups and Han people. It had reflected the legal status of Yuwen Division, Xianbei Tribe to win their support and enhance its government. On the base of Rites of Zhou, the music system of Northern Zhou also absorbed the music systems of the Northern Wei and Southern States. With the combination of its national music and tradition, it had made an innovation and formed its distinctive characteristics. Therefore, it has a profound influence.
\end{abstract}

Keywords-the Western Wei and Northern Zhou Dynasties; ritual system; music system; court music

\section{INTRODUCTION}

The Northern Zhou was established by Xianbei People with many ethnics. Han accounted for at least half of its population, so the ruling class Xianbei chose to be chinesized to maintain and consolidate its ruling. They started to learn Chinese and established and implemented the ritual and music system of Han nationality.

\section{THE CONSTRUCTION OF THE RITUAL SYSTEM OF NORTHERN ZHOU}

At the beginning of the establishment of the Western Wei and Northern Zhou Dynasties, the ritual and music system was not complete and perfect. Yuwen Tai, Zhouwen Emperor, "ordered his official Left Servant Shezhou Huida and Beihai Tangjin, Langzhong of the Ministry of Official Personnel Affairs to modify and perfect it" [1] (P4904). The ritual system became better. Later, Yuwen Tai ordered Lu Jingxuan, who were good at Six Arts, to "complement the Five Rites" [2] (P2706). He reformed the central official system according to Rites of Zhou and established the rudiment of the ritual system of Northern Zhou. However, it was really established under the reign of Yuwen Yong, Zhouwu Emperor. According to Book of Zhou - Zhouwu Emperor, Yuwen Yong set the Six Officials and Six Troops, and held a ceremony for choosing officers in the first month of the first Baoding Year (561). He commanded to follow this rite from the November of second Jiande Year (573). He called his officials and officers and invited Shamen Taoist to teach them Book of Rites separately in the first Tianhe Year (566) and third Tianhe Year (568) [3] (P64, 83, 72, 75). According to the record of Book of
Zhou · Hu Sizheng, Yuwen Yong also praised Hu Sizheng's "management with means and asked royal princes to learn from him and follow the rite of Shuxiu" [3] (P432). Yuwen Yong always followed the rites by himself after he set them, so the ritual system gradually was carried out in the royal court. At same time, he appointed Xin Yanzhi and Kou Zhi, who were familiar with these rites, to take office at local offices, and asked them to carry out the rite system in these places [4] (P489).

But from the records of Book of Sui - Rituals, the real purpose of the Northern Zhou was to fully promote the authority of the ruler and maintain the rites of Ji, Jia and Jun by complementing the Five Rites actively. For example, they established Yuanqiu System, Jiaosi System, Tianzi Temple System, Sheji Rite and Dami System in the aspect of Ji Rite, Chuzheng Rite, Tianzi Hunting System, Junchen Fuzhang System and Baji System in the aspect of Jun Rite, Pension Rite, Royal Prince Chaohui Rite, Chaori Xiyue System, Silu System and Gongji System in the aspect of Jia Rite. But the Bin Rite and Xiong Rite were inferior in the formulation and implementation.

The ritual system of Northern Zhou (including the Western Wei) mainly was established in accordance with Rites of Zhou. But it didn't completely imitate. It not only didn't recover five traditional rites entirely but also had innovative characteristics in the construction of the ritual system. This special ritual system also has the culture of both ethnic groups and Han people. It had reflected the legal status of Yuwen Division, Xianbei Tribe to win their support and enhance its government.

\section{The CONSTRUCtion OF THE Music MANAGEMENT SYSTEM IN THE NORTHERN ZHOU DYNASTY}

In ancient China, the music was played and coordinated with the rite, jointly serving the political rule, so "the king appreciates music and formulate rites when he gets victory. The greater his kingdom is, the better the music and ritual system will be" [5] (P991).

After the establishment of the Western Wei and Northern Zhou Dynasties, Yuwen Tai started the construction of ritual system as well as the construction of music system. According to the record of History of Northern Dynasties - Rulin I, "Zhouwen Emperor laid emphasis on music and rites... He ordered gifted Changsun Shaoyuan to complete the Six Music" [2] (P2706). 
The establishment of the Music Division: the Music Division of the Northern Zhou Dynasty was established based on Book of Rites . Chunguan Zongbo. It changed the setting of the Palace Music Division and implemented hierarchy system. The Grand Music Ministry was set to manage relevant issues. Later the Grand Music Ministry was altered into the Music Division. According to the record of Tong Dian, "the Grand Music Ministry was established in the Later Zhou Dynasty and administrated the music affairs. Later it was changed into the Music Division" [6] (P359). Book of Zhou · ZhouWu Emperor I recorded: "the Grand Music Ministry was changed into the Music Division in May of the Fourth Baoding Year (564)" [3] (P70).

The setting of music officials: at the beginning of the Western Wei Dynasty, the ruler mainly inherited the music official system of the Northern Wei Dynasty. In the later period, Yuwen Tai implemented Guanlong-culture-oriented policy. "Due to the complicated official system of Wei Dynasty, he ordered Su Chuo and Shangshu Ling Lubian to set the Six Officials according to Rites of Zhou" [1] (P5140). It followed the music official regime of Zhou's Grand Music Ministry System. However, the music official system wasn't maintained for a long time after the reform. "Before long, his descendants couldn't follow it" [7] (P316 - 317). It was completely abolished up to the Sui Dynasty.

The grading and division of music officials: in the Northern Zhou Dynasty, the Grand Music Ministry (later called the Music Division), charging for music issues, set music officials and divided them into five ranks, with different duties. Zhongdafu (later called Shangshi) was the highest music official. According to Volume 39 of Tong Dian, "the emperor appointed Zhongdafu to administrate the Grand Music Ministry at the highest rank, and Xiadafu as the second rank, Shangshi at the third rank, Yueshi, Yuexu, Sige, Sizhongqing, Sigu, Sichui, Siwu, Yuezhang, Zhangsanyue, Dianyiyue and Dianyongqi as Zhongshi at the fourth rank, and Yuexu, Sige, Sizhongqing, Sigu, Sichui, Siwu, Yuezhang, Zhangsanyue, Dianyiyue and Dianyongqi as Xiashi at the last rank" [8] (P266).

According to Book of Zhou, Zhou Taizu established the Six Officials and appointed Changsun Shaoyuan and $\mathrm{Hu}$ Sizheng as Zhongdafu in the Music Division. Later Zhouwu Emperor made a reformed and appointed Tang Ling as Shangshi in the Music Division.

\section{THE CLASSIFICATION OF NORTHERN ZHOU'S MUSIC STYLES}

In the Northern Zhou Dynasty, there were diversified styles of music. In general, it is divided into Han music, minority ethnic music and foreign music. Han music includes old central-plains music and new Qingshang music. The minority ethnic music includes Beidi music and western music. The foreign music includes Tianzhu music, Gaoli music and Baiji music.

Xianghe Song is the representative of the old central-plains music. In Book of Song · Music, Shen Yue said: "Xianghe is an old central-plains song. Ancient people played it with Sizhu (an traditional stringed and woodwind instrument) and coordinated with allegro" [9] (P603). Xianghe Song is the most representative masterpiece of Xianghe music style. Book of Song $\cdot$ Music has recorded 15 Xianghe songs in total [9] (P625 - 660).

New Qingshang music mainly is composed by "three Qingshang tones", old Hanwei music, Wu music and West music. "Three Qingshang tones" also is called "three Xianghe tones". The three tones are Qing, Ping and Se in Xianghe Song. Guo Maoqian quoted six songs at Qing tone, 7 songs at Ping tone and 38 songs at Se tone from Guiji Yuelu into his Music Poems [10] (P495, 441, 534 - 535). Old Hanwei songs mainly are Mingjun, Shengzhu, Gongmo and Baijiu. Wu music and West music belong to southern folk songs. Quoted from Gujin Yuelu, Music Poems recorded: "Mingxiao belongs to $\mathrm{Wu}$ music. Generally Wu music has half fold, six changes and eight verses. But Mingxiao has ten verses. The left songs are Wuzaolin, Fuyunqu, Yanguihu and Marang. The other songs were lost". West music was born in "Jingying and Fandeng. Its tone is soft and gentle, which is quite different from $\mathrm{Wu}$ music. Local people call it West music. There are 34 recorded songs, including Shichengyue and Wuyeti [10] (P604, 688 - 689).

Beidi music is a joint name of music of northern minorities, including Xianbei, Xiongnu, Qiang, Di and Xie, in the Hantang period. In the Northern Zhou period, there were two poetry styles, Huyu style and Huayu style. The background music has prominent minority characteristics. They mainly used music instruments of northern minorities and also integrated music instruments of Central Plains and the Western Regions. It was widely spread both in palace and folks. At same time, it was chinesized with time. In the Tang Dynasty, it absorbed elements of $\mathrm{Hu}$ Music, which has prompted the development of $\mathrm{Hu}$ Music. Beidi music generally produced in the Northern Wei Dynasty. Book of Tang - Music II recorded: "Beidi songs came into fashion in the Music Department of Later Wei, so History of Wei recorded Zhenren Daige" [11] (P1071-1072). In the period of Zhou Taizu, there was Beidi music in the royal court. Book of Sui - Music recorded "the staged singer has the tone of Xianbei". With further development, Beidi music was also played in the middle and late Northern Zhou and West Liang Dynasties.

In the Northern Zhou Dynasty, the Western Music mainly includes Gaochang Music [12] (P342), Guizi Music [11] (P1069), Xiliang Music [12] (P378), Kangguo Music [12] (P375), Anguo Music and Shule Music [12] (P380). When the Zhouwu Emperor was in power, the western-toned east music was very popular. Zhouwu Emperor married the daughter of the Tujue King as queen, so the Northern Zhou began to contact with countries in Western Regions frequently. At that time, all kinds of western music poured into Chang'an. Some musicians came to Chang'an to teach music of the Western Regions. The music of the Western Regions formally was introduced into the palace of Northern Zhou Dynasty. At this period, local music absorbed some elements from the Western Regions. Local people also played the Western music with metal and stone instruments according to Rites of Zhou, which made it localized. The exchange between them promoted the mutual integration of $\mathrm{Han}$ and $\mathrm{Hu}$ music. It directly laid a foundation for the Nine Ensembles Music. 
Tianzhu music, according to the record of Book of Tang · Music II, "at the time of Zhang Chonghua, Tianzhu laid emphasis on musicians and once their prince visited Shamen and he specially imparted their music [11] (P1070). Gaoli Music and Baiji Music, according to Book of Tang $\cdot$ Music II, had passed into the Song State in the Northern Dynasties. Ping Fengba of Later Wei (436) passed these two kinds of music into the north, and people of Northern Zhou called it old music. Later "the army of Zhou defeated Qi and Qi offered their music to Zhou" [11] (P1069). This music was called as new music.

\section{THE USAGE OF NORTHERN ZHOU'S COURT MUSIC AND INSTRUMENTS}

When Zhou Taizu greeted Weiwu Emperor to enter into Shanhai Guan, the court music fell into disuse. "When the officials wanted to play after victory, they played old Zhou music [12] (P287). In the first year (552) of Western Weifei Emperor, Zhou Taizu acted as regent. He ordered "Shangshu Su Chuoxiang to collect and file songs. Su Chuoxiang used the ruler of Song to measure orchestral instruments. His work hadn't been finished yet Huimin Emperor converted to Buddhism. Some officials wielded power and there were enemy from Qi State, so it was shelved" [12] (P391). Later the Ming Emperor succeeded to the throne. The court abandoned the music of Wei, but it was still "not complete" [12] (P332). Until the period of Wudi emperor, the emperor ordered $\mathrm{Hu}$ Sihui, who was good at music and rhythm, to collect lost songs, search old books and make innovation". So, the court music became "sorted and complete" [3] (P433). At same time, Northern Zhou absorbed the elements of Southern State's court music. Book of Sui · Music recorded: "the Wudi Emperor of Northern Zhou liked Xiongpi'an played with 12 drummers. Every Yuanzheng Meeting, the drummers lined up and played with formal music" [12] (P342).

Specifically, the court music of Northern Zhou was also called "six-generation music", including Huangxia, Sixia, Aoxia, Naxia, Zuxia and Shenxia. It was coordinated with "six-generation dance", including Daxia, Dahu, Dawu, Zhengde, Wude and Shanyun. Book of Sui - Music recorded: "on the Jiachen day, October, Second Jiande Year (573AD), six-generation music was formed and played in the Chongxin Palace. All officials appreciated it. Its Gongxuan was made according to 36 drum sets of Liang. They played Huangxia when the emperor came in and went out at the morning meeting, and Sixia when the prince came in and went out, Aoxia when the nobilities came in and went out, Naxia when the dukes offered jades and silks and Zuxia when treated clansmen. At the meeting 18 Dengge songs were played for the appreciation of the distinguished and notabilities. When the emperor dined, they played Shenxia and danced six-generation dance. Therefore, the court music was formally set for the service of the royal court. They created bell temperament, which was quite great. When the Xuandi Emperor succeeded to the throne, they played it in the suburban imperial sacrificial rite without changing any place [12] (P332 - 333).

In the Northern Zhou Dynasty, they played music instruments coordinated with songs or dance. In the performance, the instruments used mainly presented the combination characteristics of different instruments. The most common combination was wind instruments and string instruments. And the wind instruments played a major role in the combination. Seen from the source of instruments, Han and $\mathrm{Hu}$ instruments were played at same time and same place or at different time and same place. For example, Dunhuang Grottos · Music Scroll [13] (P22) recorded: a Buddhism story was on the mural in the 290 Cave of Dunhuang Grottos. It was about "god realization" and "taking a wife". On the mural, there was a carriage and a house. Besides the carriage people were playing Pipa, Konghou and flutes. On the left side of the house, there were two musicians. One was playing panpipe and the other was playing Pipa. One man seemed to be singing. On the Northern Buddha Stone Carving, unearthed from Shanxi Xingping, there was a band combined with eight people. The musical instruments they used were flute, panpipe, Konghou, and Pipa. The former two are central-plains instrument, and the later two are western instruments.

\section{CONCLUSION}

The Northern Zhou ritual system was constructed to meet the needs of political rule. The complete construction was quite a long process. It mainly followed the old system of Zhou State in Book of Rite, Rites and Record of Music, and absorbed the experience of former states and mixed with native ethnic elements. Such a ritual system has the characteristics of Han and Hu people. Therefore, the royal court abandoned it in the Sui Dynasty. But in all fairness the construction of Northern Zhou ritual system played an important role in reserving and inheriting music and rites of past generations. The process was a new discovery about rites and music, which greatly promoted the exchange and integration of $\mathrm{Hu}$ and Han cultures. It also has an influence of changing their national psychology and habits. In addition, it formed the music pattern of the coexistence and co-melting of all ethnic music and the dominating role of western music in the Northern Zhou Dynasty. This pattern was continued to the Sui and Tang Dynasties. It has laid a solid foundation for the establishment of court music, such as the Seven Ensembles and Nine Ensembles, and the music prosper in the Tang Dynasty.

\section{REFERENCES}

[1] Sima Guang (Northern Song Dynasty). Zizhi Tongjian. Noted by Hu Sansheng. Zhonghua Book Company, 1956.

[2] Li Yanshou (Tang Dynasty). History of Northern Dynasties. Zhonghua Book Company, 1974.

[3] (Tang Dynasty) Linghu Defen. Book of Zhou. Zhonghua Book Company, 1971.

[4] Zhao Chao. Epitaph Compilation of Han Wei, Northern and Southern Dynasties. Tianjin Ancient Books Publishing House, 1992.

[5] Sun Xidan (Qing Dynasty). Explanations of Rites. Zhonghua Book Company, 1989.

[6] Du Yue (Tang Dynasty). Tong Dian. Yuelu Publishing House, 1995.

[7] Chen Yinque. Histories of Wei, Jin, Southern and Northern Dynasties. Edited by Wan Shengnan. Huangshan Press, 1987.

[8] Yong Rong and et al (Qing Dynasty). Official List of Past Generations. Zhonghua Book Company, 1985. 
[9] Shen Yue (Southern Liang). Book of Song. Zhonghua Book Company, 1974.

[10] Guo Maoqian (Southern Song). Music Poems. Zhonghua Book Company, 1979.

[11] Liu Xu (Later Jin). Book of Tang. Zhonghua Book Company, 1975.

[12] Wei Zheng et al (Tang Dynasty). Book of Sui. Zhonghua Book Company, 1973.

[13] Zheng Ruzhong. Dunhuang Grottoes. Commercial Press, 2002. 